\title{
O lugar da fala \\ conversas entre o jongo brasileiro e 0 ondjango angolano
}

\section{Paulo Dias ${ }^{1}$}

\section{Resumo}

A palavra jongo refere-se a uma tradição popular afro-brasileira com música, dança e poesia. No entanto, o fato de o termo ser utilizado em comunidades não-jongueiras com outros significados denota uma abrangência semântica maior. A aproximação especulativa de diferentes aspectos da tradição jongueira com estruturas correlatas no ondjango, conselho comunal do povo ovimbundo de Angola (prática da fala coletiva dialogada, uso de formas orais simbólicas, existência de diferentes modalidades dialógicas etc), desvela sua dimensão de lugar da fala, em consonância com princípios civilizatórios africanos. Seria o jongo uma rearticulação diaspórica do ondjango angolano,ou de alguns de seus aspectos, ressignificados e retrabalhados pelos banto-descendentes em resposta às condições restritivas da escravidão?

\section{Palavras-chave}

Jongo, ondjango, tradição oral afro-brasileira.

Recebido em 29 de março de 2014

Aprovado em 5 de julho de 2014

DIAS, Paulo. O lugar da fala: conversas entre o ondjango angolano e o jongo brasileiro. Revista do Instituto de Estudos Brasileiros, Brasil, n. 59, p. 329-368, dez. 2014.

DOI: http://dx.doi.org/10.11606/issn.2316-901X.v0i59p329-368

1 Associação Cultural Cachuera!, São Paulo, SP, Brasil. 


\title{
The Place of Speech Dialogues between Brazilian Jongo and Angolan Ondjango
}

\section{Paulo Dias}

\begin{abstract}
The word jongo denotes an Afro-Brazilian popular tradition which incorporates music, dance and poetry. However, the same term occurs, with different meanings, among negro comunities not related with jongo performance, which points out it's broader semantic range. The speculative confrontation of different aspects of jongo tradition with similar structures found in onjango, comunity council of the ovimbundu of Angola (such as the practice of collective speech, the use of metaphoric wordings, the existence of different dialogical modalities ) led to the comprehension of jongo as the place of speech, consonant with African civilization principles. Could jongo represent a diasporic rebuilding of African institution of spoken word, shaped by the restrictive conditions of slavery?
\end{abstract}

Keywords

Jongo, Ondjango, Afro-Brazilian Oral Tradition. 


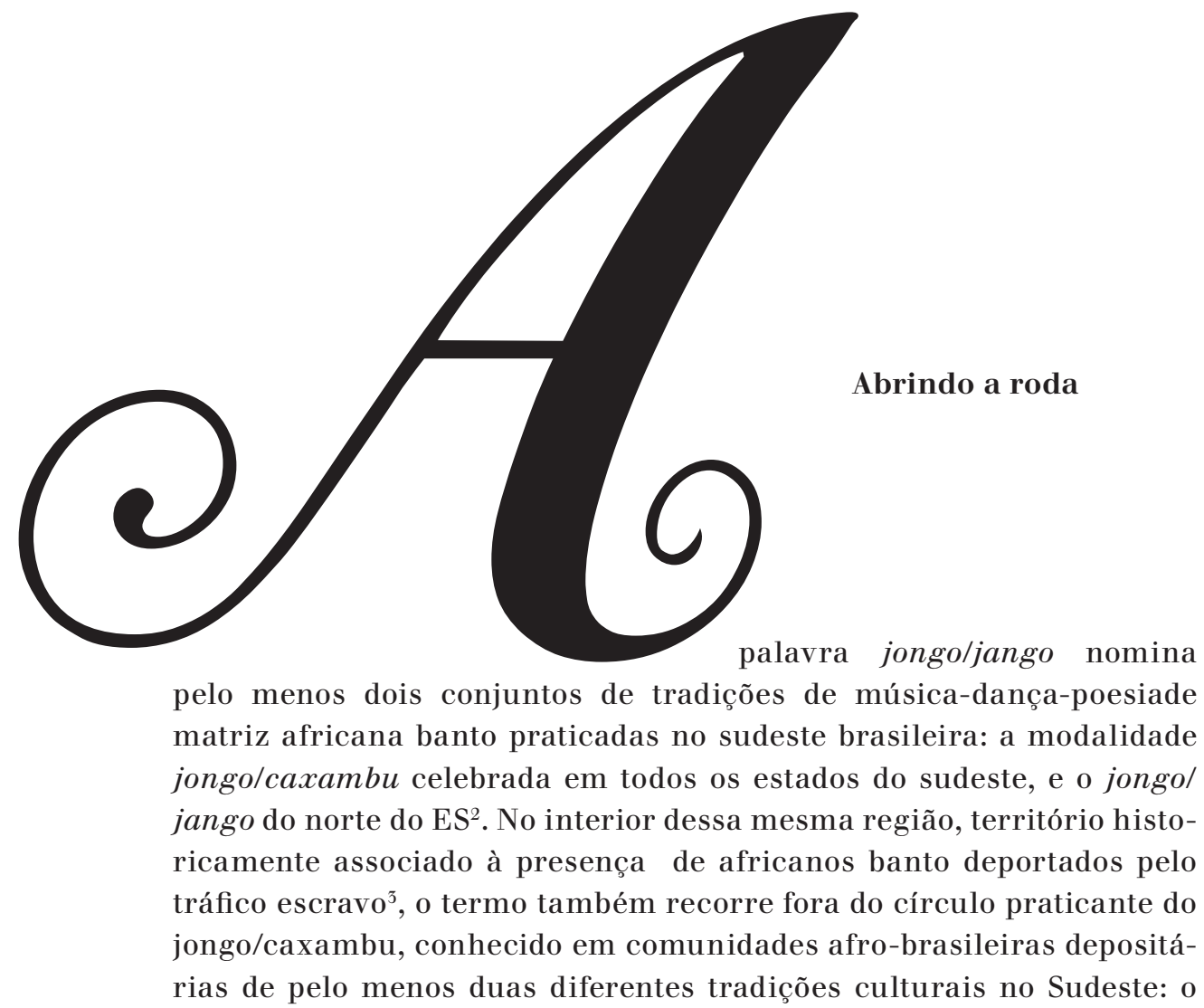

2 Em seu sentido atual, a palavra jongo designa uma expressão cultural afro-brasileira unindo toques de tambores, canto, dança e improviso poético, que acontece geralmente à noite, perto de uma fogueira. Os jongueiros se revezam na cantoria dos pontos (cânticos), a qual pode assumir a forma de um desafio. A dança varia de coreografias individuais executadas por um solista ou casal solista evoluindo no meio do círculo de participantes a coreografias coletivas em roda anti-horária. A área jongueira estende-se ao longo do Vale do Paraiba e regiões adjacentes; prolonga-se, para o norte, até o Espírito Santo, acompanhando as áreas onde foi cultivada a cana e sobretudo o café. Nos estados do RJ, MG e ES é chamado de caxambu. No norte do ES, jango ou jongo designa uma modalidade distinta, compreendendo uma suíte de danças executadas por mulheres e podendo assumir a forma de um cortejo nas festas do catolicismo popular.

3 Entre 1820 e 1888 , os registros de procedência (segundo o porto de embarque) dos escravos destinados à plantagem cafeeira indicam que $50 \%$ provinham de Angola, Benguela, Congo e Cabinda, seguidos em número pelos Moçambiques. Cerca de 30\% eram originários de Cabundá, Cassanje, Ganguela, Inhambane, Mocena, Mossambe e Rebolo. Um número menor provinha de "Mina" ou "Calabar". Cf. STEIN, Stanley J. Vassouras, um município brasileiro do café, 1850-19oo. Rio de Janeiro: Nova Fronteira, 1985, passim. 
batuque de umbigada (SP) e o reinado/congado (MG) ${ }^{4}$. Aí jongo assume sentidos outros, diferenciados porém referentes a um universo cultural banto-sudestino comum efortemente impregnado da marca ovimbundo $^{5}$. Turi Vimbundo- Terra de Preto-, como está escrito na placa à entrada da Comunidade Negra do Cafundó, associando o etnônimo ovimbundo a negro ${ }^{6}$. Os vocabulários banto-africanos, convertidos na diáspora em línguas de comunicação intragrupal que atualmente possuem uns poucos falantes em comunidades negras do Sudeste brasileiro ${ }^{7}$, revelam presença majoritária de termos umbundo, de acordo com a linguista Sônia Queirós ${ }^{8}$. O dialeto Benguela utilizado pelo saudoso capitão João Lopes e outros capitães da Irmandade de Nossa Senhora do Rosário de Jatobá - Belo Horizonte-MG, faz referência à cidade angolana que foi o principal porto de embarque dos ovimbundo para o Brasil durante o tráfico atlântico.

Tento aqui identificar possíveis conexões entre o ondjango ovimbundo ${ }^{9}$, conselho comunal masculino que centraliza a vivência sociocultural nas aldeias do oeste angolano, e a tradição cultural afro-brasileira do jongo/caxambu, tradição de música-dança-poesia praticada no Sudeste do Brasil, tendo em vista o processo de transferência massiva de populações entre essas duas regiões ocorrido durante o tráfico escravo, sobretudo no século XIX. O objetivo é analisar em paralelo, no plano mais geral da história e das relações sociais, e especificamente no âmbito multifacetado da comunicação intra-grupal e de suas formas literárias orais, certas estruturas que parecem coincidir nos dois casos. A ideia em hipótese é que o jongo brasileiro pode estar ligado, em sua origem, à rearticulação

4. O batuque de umbigada abrange as cidades paulistas de Capivari, Piracicaba e Tietê; o grupo de congadeiros a que nos referimos é o da Comunidade Negra dos Arturos, em Contagem - MG.

5 Segundo Martinho Kavaya, os Ovimbundu constituem "o maior grupo da metade Oeste de Angola, subindo da beira-mar para as terras altas [...] Com a população acima de 4.500.ooo habitantes [...] comunica-se na língua umbundu”. Cf. KAVAYA, Martinho. Educação, cultura e cultura do "Amém": diálogos do Ondjango com Freire em Ganda-Benguela/Angola. 2006. 304, f. Dissertação (Mestrado em Educação) - Faculdade de Educação, Universidade Federal de Pelotas, Pelotas, 2oo6, p. 56. Adotamos aqui a forma aportuguesada ovimbundo/umbundo.

6 Na cupópia, língua de resistência falada no Quilombo do Cafundó, em Salto de Pirapora - SP, construída a partir de vocabulário banto.

7 Como Jatobá, em Belo Horizonte-MG, Cafundó, em Salto de Pirapora-SP, Bau e Ausentes em Milho Verde - MG, Mato do Tição em Jaboticatubas-MG, Tabatinga-MG, entre outras.

8 Sônia Queirós, linguista da Universidade Federal de Minas Gerais, em comunicação pessoal.

9 Não temos notícia da vitalidade do ondjango na Angola atual. 
em ambiente diaspórico de aspectos da instituição angolana do ondjango, preservando-se o sentido fundante de instância coletiva da fala dialogada. Esclarecemos que este artigo se apóia, no caso do ondjango angolano, em descrições etnográficas constantes de trabalhos acadêmicos, em especial a dissertação do educador angolano Martinho Kavaya ${ }^{10}$, sem termos experimentado a vivência em campo, a qual, já em relação ao jongo valeparaibano, constituiu a base dos conhecimentos aqui apresentados.

O campo dos estudos afro-brasileiros, tradicionalmente voltados para os aportes culturais e históricos dos povos ditos sudaneses da África Ocidental no Nordeste brasileiro, tem-se enriquecido, nas últimas décadas, com importantes investigações acerca dos banto do Sudeste, como as que apontam a emergência de uma cultura identitária banto unificada em território sudestino brasileiro, que se teria configurado a partir de semelhanças civilizatórias entre povos oriundos da área do Congo e de Angola.

O etnomusicólogo congolês Kazadi Wa Mukuna assinala uma notável unidade cultural entre os estados autônomos que constituíam o primeiro império do Kongo, com apogeu por volta do século XVI - Angola, Benguela, Kongo, Loango -, assim como entre os povos tributários de seu segundo império e entre outros grupos da Bacia do Zaire. Em 1513, o Manikongo já se aliara aos portugueses no fornecimento de mercadoria humana para o nascente escravismo mercantilista. Segundo o autor,

A unificação, que podia ter sido a consequência da origem comum das tribos Bantu, fato corroborado pela noção linguística baseada no sistema das línguas de classes, tem sido alimentada, por certo, por diversas atividades, tais como contatos nos campos de batalha, intercâmbio comercial, migrações, etc, que ocorreram, na maior parte, depois da já mencionada deslocação do primeiro império Kongo. ${ }^{11}$

10 KAVAYA, Martinho. Educação, cultura e cultura do "Amém": diálogos do Ondjango com Freire em Ganda-Benguela/Angola. Kavaya propõe a aproximação de conceitos educacionais característicos do complexo cultural angolano do ondjango às formulações desenvolvidas por Paulo Freire. Como fonte etnográfica para o ondjango, Kavaya utiliza principalmente a obra do Padre José Nunes, $O$ Ondjango e a Inculturação em Africa / Angola. Não tive acesso a outras descrições mais detalhadas e atuais sobre o ondjango, não obstante a busca intensiva empreendida.

11 MUKUNA, Kazadi Wa. Contribuição bantu na música popular brasileira: perspectivas etnomusicológicas. São Paulo: Terceira Margem, 200o, p. 28-29. 
Ao se estabelecer o tráfico, novos contatos culturais entre povos bantu acontecem nos entrepostos onde os escravizados permaneciam confinados meses a fio antes de serem embarcados:

[...]o tempo que os escravos passavam juntos foi logicamente suficiente para que elaborassem e homogeneizassem um mundo de experiências que, implicitamente, figuraria em suas consciências", configurando-se novos "quadros coletivos de memória". ${ }^{12}$

Apoiando-se em autores como Craemer, Vansina e Fox, os quais confirmam a unidade cultural banto na África Central, o historiador estadunidense Robert Slenes estuda as causas da formação daquilo que denomina uma "proto-nação bantu" no Sudeste do Brasil:

No contexto do Centro-Sul brasileiro, a falta de socialização de uma grande proporção de novos escravos nos aspectos mais recônditos, e portanto mais específicos, de suas culturas de origem, antes teria facilitado a "transculturação" (o termo é do próprio Moreno Fraginals) entre africanos, ou seja, a superação de fronteiras étnicas antigas e a formação de uma nova identidade "bantu". ${ }^{13}$

Adiante, o autor aponta as semelhanças linguísticas entre banto pertencentes a diferentes grupos aportados no Sudeste como fator de integração entre eles: "Nesse contexto, a palavra que os escravos detinham em comum pode ter deixado de ser para eles apenas um significante, revelando afinidades mais profundas, para tornar-se, ela mesma, um dos elementos constitutivos de sua identidade". ${ }^{14}$

\section{Sentidos de jongo no Sudeste}

Entre os congadeiros da Comunidade Negra dos Arturos, em Contagem-MG, cantar jongo é lembrar de pessoas que já se foram, capitães antigos e seus reinados, durante o ritual da matina, que

12 MUKUNA, Kazadi Wa. Contribuição bantu na música popular brasileira, p. 72.

13 SLENES, Robert W. Na senzala, uma flor. Rio de Janeiro: Nova Fronteira, 1999, p. 216.

14. SLENES, Robert W. Na senzala, uma flor, loc. cit. 
acontece de madrugada, antes do levantar do sol ${ }^{15}$. Para a batuqueira Anecide Toledo, de Capivari-SP, jango corresponde ao momento do can-can, coreografia também chamada sobe-e-desce, dançada igualmente ao nascer do dia, quando se finda o Batuque de Umbigada. Lembrar dos antepassados, suas danças e ensinamentos, parece ser a acepção residual de cantar/dançar jongo nessas comunidades congadeira e batuqueira. Buscando sentidos mais extendidos, pode-se associar jongo a coisas dos antigos, tradição ancestral carregadada presença espiritual dos troncos velhos da comunidade, assim como o termo ingoma/angoma ${ }^{16}$.

Já entre os jongueiros, o termo assume significados distintos, mas que também se inter-relacionam quando interpretados no contexto sociocultural mais amplo da prática do jongo/caxambu. Questionados sobre o significado da palavra jongo, eles explicam: divertimento (Joaquim Honório dos Santos, S. Luis do Paraitinga), convite à brincadeira (Cunha) ${ }^{17}$, saudades - saudades da África, como aponta Zé Carlos (José Carlos dos Santos) de Guaratinguetá - sentido correlato ao que circula nas comunidades extra-jongueiras mencionadas. Já divertimento ou brincadeira caracteriza recorte do aspecto lúdico da tradição, a dança com tambores, assim como o engenhoso embate de palavras.

A mais completa tradução de jongo parece passar ao largo dos esforços de seus depositários quando são solicitados pelo pesquisador a definir ou traduzir. Ocorre é que, na contingência de dar pronta resposta ao perguntador, eles acabam por iluminar esta ou aquela faceta de sua tradição que lhes aparece como passivel de ser compreendida por leigos (dança, música, tambor, divertimento), descartando outras dimensões reveladoras de maior complexidade. Em relação ao jongo, assim como a outras modalidades expressivas afro-brasileiras de caráter espiritual ou religioso, também interfere no processo de enquete a necessidade de se manter segredos de ordem iniciática.

Nas situações em que as falas dos entrevistados estão menos guiadas por uma preocupação em definir, situação da conversa solta, do diálogo entre iguais (veremos adiante...), revela-se um âmbito mais amplo, generoso, menos seletivo, fragmentador, de sentidos;

15 Comunicação pessoal do linguista André Bueno.

16 Significando tambor, o termo banto ngoma é, igualmente, referência metonímica à dança e à própria comunidade herdeira de formas de expressão ancestrais afrobrasileiras.

17 Cf. ARAUJO, Alceu Maynard. Folclore nacional, Volume 2. São Paulo: Melhoramentos, 1964 . 
quem conhece o jongo a fundo sabe da dificuldade de conceptualizá-lo em poucas palavras. "O jongo hoje é um clube", disse-me certa vez Hélio Jeremias (Helinho), jovem jongueiro do Bairro Tamandaré, em Guaratinguetá - SP, ao comentar a abertura recente da roda a mulheres e crianças. Outro participante do mesmo grupo ponderou que "a história do Brasil se aprende aqui [na roda de jongo]", e não só na escola e nos livros. Atentemos para os conceitos de clube e lugar de aprendizado da história, abertos o suficiente para, a partir de um vôo alto, permitir-nos divisar a complexidade sócio-semântica de jongo; ambas explicações concorrem complementarmente para delinear o jongo como lugar de encontro ou instituição onde se veiculam conhecimentos ancestrais, dotados de profundidade histórica.

Entre os pesquisadores, houve tentativas de se buscar uma etimologia para o termo jongo, associada a uma possível matriz étnica. A hipótese que nos parece mais acertada é a do compositor e pesquisador de cultura afro-brasileira Nei Lopes, que diz ser o jongo uma dança originária talvez da região de Benguela, na atual Angola; seu nome origina-se, provavelmente, do umbundo onjongo, nome de uma dança dos Ovimbundos ${ }^{18}$.

\section{Oralidade, fala, diálogo}

O historiador belga Jan Vansina ressalta o papel central da palavra falada na África:

As civilizações africanas, no Saaara e ao sul do deserto, eram em grande parte civilizações da palavra falada, mesmo onde existia a escrita, [...] relegada a um plano secundário em relação às preocupações essenciais da sociedade. [...] Uma sociedade oral reconhece a fala não apenas como um meio de comunicação diária, mas também como um meio de preservação da sabedoria dos ancestrais, venerada no que podríamos chamar elocuções-chave, isto é, a tradição oral. A tradição pode ser

18 LOPES, Nei. Enciclopédia brasileira da diáspora africana. São Paulo: Selo Negro, 2004, p. 365. Embora credite aos ovimbundo de Benguela uma possível origem do termo jongo, o autor associa onjongo a uma dança, e não ao conselho comunal tradicional. 
definida, de fato, como um testemunho transmitido verbalmente de uma geração para outra. ${ }^{19}$

Tratando da tradição oral no continente africano, o historiador maliense Amadou Hampaté Bâ salienta que

A tradição oral é a grande escola da vida, e dela recupera e relaciona todos os aspectos.[...] Ela é ao mesmo tempo religião, conhecimento, ciência natural, iniciação à arte, história, divertimento e recreação, uma vez que todo pormenor sempre nos permite remontar à Unidade primordial. [...]Uma vez que se liga ao comportamento cotidiano do homem e da comunidade, a "cultura" africana, não é, portanto, algo abstrato que possa ser isolado da vida. ${ }^{20}$

Em grande parte das culturas africanas, as atribuições da palavra falada vão além da comunicação entre os homens e da transmissão do saber; ela atua também como como mediadoradas relações entre a sociedade humana e o mundo espiritual, e está profundamente relacionada a uma visão religiosa do mundo. Na África, a palavra proferida é objeto de veneração e ao mesmo tempo de muitos cuidados, uma vez que sua origem divina a investe do poder de construir e destruir, constituindo-se, como afirma Hampaté Bâ, no "grande agente ativo da magia africana". ${ }^{21}$

A palavra, como força e símbolo, penetra tudo, encontra-se em tudo, reina em toda a parte, multiplica os seus modos de intervenção na existência humana. ${ }^{22}$

Entre os banto, a palavra está ligada intrinsecamente a quem a pronuncia, constituindo a expressão de sua pessoalidade, - visão corroborada por Hampaté Bâ, que afirma que o homem é a palavra que emite. A palavra promove a comunicação, entendida como

19 VANSINA, Jean. A tradição oral e sua metodologia. In: KI-ZERBO, Joseph (org.). História geral da Africa, Volume 1 - metodologia e pré-história na África. São Paulo: Ática; [Paris]: Unesco, 1982, p. 157.

20 HAMPATÉ BÂ, Hamadou. A tradição viva. In: KI-ZERBO, Joseph (org.), História geral da Africa, Volume 1 - metodologia e pré-história na África, p. 183.

21 HAMPATÉ BÂ, Hamadou. A tradição viva, p. 186.

22 THOMAS, L-V; LUNEAU, R. "La terre africaine et sés religions". Paris: Larouse, 1975, p. 78. Apud KAVAYA, Martinho. Educação, cultura e cultura do "Amém": diálogos do Ondjango com Freire em Ganda-Benguela/Angola, p. 130. 
prolongamento da pessoa, como vida participada. As narrativas e conversas ao pé do fogo, a troca de experiências, ideias e impressões entre homens, entre mulheres, quando se encontram à noite em torno da fogueira, constituem uma prática cotidiana e fundamental nas aldeias angolanas, e a essa atividade todos se entregam com grande prazer e harmonia durante horas a fio ${ }^{23}$.

Para os ovimbundo de Angola, a palavra umbundo onjango (também grafada na forma fonética ondjango, que adotaremos aqui), designa o espaço/instituição social entendido como casa/lugar de conversa ${ }^{24}$. Estrutura análoga é encontrada também entre os ambundo , referida como njango ou jango na língua quimbundo ${ }^{25} \mathrm{e}$, nas aldeias nganguela da parte oriental de Angola, identificado como ndzango na língua mbwela ${ }^{26}$. Trata-se de um conselho de aldeia que centraliza grande parte da atividade comunicacional nessas populações tradicionais. Entre os ovimbundo, ondjango pode tanto nomear a prática ritualizada de várias formas de interlocução coletiva comunitária (espaço social), quanto o espaço físico circular, aberto nas laterais e coberto com teto de palha, onde são realizadas os encontros dos homens da comunidade ${ }^{27}$. Em sua atribuição de centro da vida comunitária, o ondjango tem, hoje, de dividir espaço com instituições de origem européia como a escola e as igrejas. Não obstante, sua presença em Angola permanece arquetípica, insinuando-se até mesmo no português falado no país, onde o termo quimbundo jango significa associação, coletivo, grupo, conforme lemos em sites da internet (jango literário, jango esportivo etc).

Acredito que a tradição afro-diaspórica do jongo possa estar relacionado, histórica, social e culturalmente, ao ondjango angolano, e é em defesa dessa ideia que, deste ponto em diante, passo a argumentar. Ao serem transferidos para o sudeste brasileiro, tanto ovimbundo quanto ambundo, dentre os povos majoritários que compoem o contingente banto fixado no Sudeste brasileiro,

23 AltunA, Pe. Raul de Assua. Cultura Tradicional Bantu. 2. ed. Luanda: Ed. Secretariado Arquidiocesano de Pastoral, 1993, p. 86.

24 KAVAYA, Martinho. Educação, cultura e cultura do "Amém": diálogos do Ondjango com Freire em Ganda-Benguela/Angola, p. 25.

25 SÁ, Ana Lúcia Lopes de. Raízes de tradições orais em romances históricos angolanos. In: Marti Pérez, Josep; Aixelà Cabré, Yolanda. Estudios Africanos: Historia, Oralidad, Cultura. Barcelona: CEIBA Ediciones, 2008, p. 131-154.

26 KUBIK, Gerhard. Mukanda na makisi/Angola. Museum collection Berlin(West), Berlim, v. 11, 1981. Encarte do LP.

27 KAVAYA, Martinho. Educação, cultura e cultura do "Amém": diálogos do Ondjango com Freire em Ganda-Benguela/Angola, p. 145. 
certamente carregaram consigo essa instituição da palavra, entranhada que estava nos seus modos de pensar, agir e sentir, em seu viver cotidiano, como princípio civilizatório ancestral. A establidade do ondjango, no tempo e no espaço, nos territórios angolanos de onde aqueles povos banto foram arrancados pelo tráfico, a partir do século XVII principalmente, em parte nos autoriza a hipótese acima. Afora os liames históricos, as semelhanças estruturais entre jongo e ondjango, recorrentes em diversos aspectos da organização social, dos modos comunicacionais e das formas orais utilizadas em ambos, aparecem como igualmente relevantes para essa aproximação.

No conselho comunal ovimbundo do onjango, os processos de comunicação se estruturam em torno do diálogo. Trata-se de uma forma privilegiada de se dar a conhecer, de produzir/propagar conhecimento, de se indentificar e fortalecer como grupo, comum a muitas civilizações africanas da oralidade. Nos olonjango (plural de onjango), as pessoas se sentam em círculo para conversar, de maneira não-hierárquica e participativa, tendo ao centro uma fogueira. Nesse espaço, estabelecem-se diferentes categorias de conversa onde as questões e aflições individuais são submetidas ao coletivo, em atos de de compartilhamento solidário de experiências vivenciais.

Em minhas primeiras incursões pelas rodas de jongo e de candombe $^{28}$, vinha-me sempre a impressão de estar diante de uma espéciede diálogo ritual, codificado e metafórico. No candombe, por vezes ouvia : "fala, candombeiro!", ou "quem vai falar?", marcando o chamamento para que os participantes se expressassem pelo canto $^{29}$. Para entoar seu ponto (poema-cantiga), o candombeiro, assim como o jongueiro, saúda primeiro os tambores, emblemas sagrados de ancestralidade, e os toca com um dos ombros para marcar o final de sua asserção. Um outro virá trazer resposta, ou ponderar sobre suas palavras, utilizando-se para isso de formulações simbólicas ${ }^{30}$.

No jongo, os termos cachuera ou machado interrompem o fluxo de música-dança-poesia para se obter o direito de colocar ponto, cujo assunto pode estar alinhado, encadeado, com o dos versos de quem cantou antes. Por exemplo, o alinhamento do tatu entabulado entre

28 O candombe é tradição banto de Minas Gerais aparentada ao jongo, praticado ritualmente nas irmandades negras de Nossa Senhora do Rosário.

29 Comunidade dos Arturos, Festa de Nossa Senhora do Rosário, 1992, registro do Acervo da Associação Cultural Cachuera!

30 DIAS, Paulo. Jongo e Candombe, primos-irmãos: estudo comparativo de duas tradições banto-brasileiras do Sudeste. In: PEREIRA, Edimilson de Almeida (org.). Um tigre na floresta de signos: estudos sobre poesia e demandas sociais no Brasil. Belo Horizonte: Mazza Edições, 2010, p. 602. 
Mestre Lico Sales, Zé de Toninho e João Rumo, do jongo da Várzea do Gouveia, em Cunha-SP, 1993:

Mestre Lico: "tatu tá velho/ (coro) mas sabe negá o carreiro". Zé de Toninho: "Cachuera, irmão! (entoando:) ô, olha lá senhor jonguero/ prá mim océ é um home fraco// esse tatu tá véio/(coro) mas é 'costumado no buraco".

João Rumo: “Cachuera! (entoando) Eh, meu Deus do céu/ esse tatu pode tá véio/ //(coro) mais não cai nessa gaiola”.

Zé de Toninho: "Cachuera, irmão! (entoando) Meu senhor jonguero/ escute o que eu tô falando/ esse tatu é veio/ mai' ele vive cavucando// (coro): aia iêl iê iál esse tatu é vélho/ mai' ele vive cavucando". ${ }^{31}$

Os muitos anos de vivência em campo trouxeram-me a certeza de que tanto jongo quanto candombe adotavam uma estrutura dialógica, caracterizada pela transitividade temática entre diferentes cantores. Ouvi da boca dos mais velhos que o jongo é como uma conversa, e também que deve ter pergunta e resposta. Mesmo os jongueiros jovens, que confessam não saber mais responder ao ponto de outrem nos moldes da tradição, dificilmente cantam gratuitamente, mas sempre na intenção de lembrar de uma pessoa querida ou de tematizar algum assunto ou acontecimento na roda. A intransitividade dos pontos não implica necessariamente na ausência da intenção de conversar.

Retomando a ideia de jongo-associação (clube) e de jongo-história, que instituição seria essa a do jongo sudestino, e qual o seu papel nos processos históricos e sociais protagonizados pelas populações banto-descendentes do sudeste brasileiro? Ao que parece, há mais relações entre o onjango/jango angolano e o jongo/ jango brasileiro do que a simples semelhança fonética. Nas duas instituições, africana e diaspórica, sobressai a ideia nuclear de casa da conversa ou lugar da fala, espaço socialmente demarcado para se trilhar coletivamente os variados e potentes caminhos da palavra proferida. Em ambas, o modo privilegiado de enunciação coletiva é o diálogo. Não se trata de conversa solta, porém submetida a convenções de ordem social, artístico-literária e religiosa, as quais orientam a sucessão e a articulação das falas entre si.

31 CD Batuques do Sudeste, faixa 7. São Paulo: Associação Cultural Cachuera/Itaú Cultural, 1999. O termo tatu, assim como as características comportamentais do bicho, servem para metaforizar uma pessoa conhecida do grupo de jongueiros. 


\section{Instituição coletiva da falana África e na diáspora}

Segundo o missionário Nunes ${ }^{32}$ apud Kavaya ${ }^{33}$, que estudou o ondjango na província angolana de Kwanza Sul visando utilizá-lo como modelo de evangelização, o ondjango "destinava-se ao controle diário da vida dos grupos humanos (...) em sociedades pequenas". Trata-se do que Katokee Ndagala ${ }^{34}$ apud Kavaya ${ }^{55}$ definem como "parlamento tradicional", pelo qual, "as sociedades africanas logravam uma vida democrática".

Martinho Kavaya, tratando especificamente do ondjango entre os ovimbundo do Planalto Central de Angola (Benguela, Huambo, Bié), identifica três dimensões semânticas no termo: o grupo de pessoas (1) que, no espaço geográfico(2) realiza a reunião, o encon$\operatorname{tro}(3)^{36}$. Ondjango relaciona-se etimologicamente, segundo esse autor, ao complexo cultural-linguístico umbundo do centro-sul de Angola, sendo palavra composta por aglutinação: Ondjo (casa) + Ohango (conversa); <ondjo y'ohango> (casa de conversa). Ondjo ${ }^{57}$, casa, tem seu sentido ampliado para qualquer lugar onde ocorra uma reunião de homens para debater assuntos de interesse comum; ohango refere-se ao diálogo sobre assunto sério entabulado de igual para igual entre duas ou mais pessoas dispostas em círculo e mediado por um osekulu, homem mais velho dotado de experiência vital.

Enquanto espaço do encontro, conforme referido pelo radical ondjo, ondjango é

...casa de conversa, de reunião, de hospedagem, de partilha de bens/refeição/serviços, de educação/iniciação sociocultural, de entretenimento e/ou de fazer justiça. Antes de tudo, se trata de

32 NUNES, José M. V. da Silva. Pequenas comunidades cristãs - O Ondjango e a inculturação em África/Angola. Porto: UCP, 1991.

33 K AVAYA, Martinho. Educação, cultura e cultura do "Amém": diálogos do Ondjango com Freire em Ganda-Benguela/Angola, p. 144.

34 KАTOKE, Israel K.; NDAGALA, D. K. El parlamento tradicional en la República Unida de Tanzânia. In: UNESCO. Aspectos sociopolíticos del parlamento tradicional en algunos países africanos. Barcelona: Serbal/UNESCO, 1982, p. 62-78.

35 KAVAYA, Martinho. Educação, cultura e cultura do "Amém": diálogos do Ondjango com Freire em Ganda-Benguela/Angola, p. 145.

36 KaVAYA, Martinho. Educação, cultura e cultura do "Amém" diálogos do Ondjango com Freire em Ganda-Benguela/Angola, p. 146.

37 Os termos onjó, conjó, injó, inzo significando casa ou lugar estão presentes em vocubulários banto-brasileiros. Por exemplo, onjó sacramento=igreja (Jatobá, Belo Horizonte - MG), injó do andaru=fogão (lugar do fogo; Cafundó, Salto de Pirapora - SP). 
uma casa, ponto de partida e ponto de confluência; de uma casa com as condições de se poder sentar, reunir junto de alguns mais-velhos, trata-se de um lugar de encontro (reunião). ${ }^{38}$

Segundo descrição do antropólogo Wilfrid D. Hambly,

No centro da aldeia fica a casa comunal onde todos os homens e os rapazes acima de quatro anos de idade se reunem para fazer refeições, sendo o alimento trazido pelas mulheres. $\mathrm{O}$ onjango é o local de assembléia para a discussão dos assuntos da aldeia. Uma casa desse tipo em Bailundu é de forma circular, com diâmetro de dezessete pés. No centro do onjango, pedras demarcam o local da fogueira. ${ }^{39}$

A dimensão de centralidade do ondjango na vida das aldeias ovimbundo é destacada por Kavaya:

Lugar respeitado, quase sagrado, e era da consciência da comunidade ser aquele espaço o centro da vida comunitária, da aldeia; o centro onde passava e dimanava a corrente vital do clã, de onde fluía o respeito e as decisões importantes em prol da comunidade. ${ }^{40}$

Na opinião do presbítero católico Geraldo Amândio Ngunga, pertencente ao subgrupo Vanganda, "O ondjango é para os Vanganda, e creio para o Bantu, um símbolo de vida, de aprendizagem e transmissão de conhecimentos dos mais velhos para as gerações, enfim é [...] a universidade de vida". ${ }^{41}$

Citando Altuna ${ }^{42}$, Kavaya salienta também o papel formador das escolas de iniciação, quando os rapazes estão reclusos e distantes de suas casas:

38 K AVAYA, Martinho. Educação, cultura e cultura do "Amém”: diálogos do Ondjango com Freire em Ganda-Benguela/Angola, p. 146.

39 HAMBLY, Wilfrid D. The Ovimbundu of Angola. Chicago: Field Museum Press, 1934. P. 209. (tradução nossa)

40 KAVAYA, Martinho. Educação, cultura e cultura do "Amém": diálogos do Ondjango com Freire em Ganda-Benguela/Angola, p. 146.

41 KAVAYA, Martinho. Educação, cultura e cultura do "Amém": diálogos do Ondjango com Freire em Ganda-Benguela/Angola, loc. cit.

42 ALtuna, Pe. Raul de Assua. Cultura Tradicional Bantu. 
Promovia-se uma formação integral de modo que a criança exercesse positivamente seu papel na vida comunitária. Tratava-se de uma educação que tinha muito a ver com a tradição, a religião e a ética comunitária. Era uma autêntica escola do ser, existir e do mundo da vida, conhecimento legados pelos ancestrais. Tratava-se, ainda, de uma escola de cidadania, pois contemplava os direitos e deveres sociais, enquanto membro da comunidade. ${ }^{43}$

No Brasil, sob o jugo da escravidão, os povos banto-africanos portadores dessas instituições tradicionais de transmissão e vivificação da palavra ancestral, fundadas em princípios coletivos e democráticos, empenharam-se em desbravar caminhos e cavar espaços estratégicos que permitissem restaurar ao menos parte de suas práticas nesse campo.

No caso dos povos ioruba e ewe-fon, os candomblés estabelecemse como instituições autônomas propiciando congraçamento étnico e veiculação de saberes tradicionais, religiosos ou não, e a consequente disseminação de valores civilizatórios que rearticulam parcelas de uma cosmovisão africana no Brasil. Associada à vida dos cativos africanos em ambientes urbanos, os ilê ou casas de religião jeje-nagô serviram de modelo para a organização do culto também entre outras etnias, inclusive banto - os candomblés congo-angola e os candomblés de caboclo ${ }^{44}$.

Porém nos interessam mais, aqui, as formas de organização dos banto no sudeste brasileiro, distanciadas da esfera de influência dos candomblés. Houve, por certo, articulações religiosas complexas como a das Irmandades Negras de Nossa Senhora do Rosário, São Benedito, Santa Ifigênia, que se disseminaram por todo o Brasil e sobretudo em Minas Gerais. Entre as maciças paredes dos templos católicos, negociando o beneplácito da sociedade escravista, africanos e afrobrasileiros lograram articular espaços de reunião, adaptando ao contexto diaspórico práticas culturais especificamente banto-africanas, como a eleição de reis representando dinastias ancestrais étnicas do Congo e de Angola (associada ao culto a antepassados), cujos cerimoniais públicos eram incluidos no calendário católico de festejos.

43 KAVAYA, Martinho. Educação, cultura e cultura do "Amém": diálogos do Ondjango com Freire em Ganda-Benguela/Angola, p. 62.

44. BASTIDE, Roger. As religiões africanas no Brasil. São Paulo: Pioneira, 1989. 
Fora dos domínios da igreja, embora incorporando elementos do catolicismo popular, e longe dos candomblés nordestinos, florescem no Sudeste formas religiosas de matriz banto como a cabula (ES) e a macumba (RJ). Diferentemente dos candomblés e seus templos, na origem essas religiões estruturam-se como cultos domésticos voltados sobretudo para a cura e aconselhamento através da intercessão de ancestrais espirituais, incorporados em médiuns. No início do século XX, no bojo de um movimento de legitimação das crenças afro-brasileiras nas metrópoles sudestinas, com a adesão de fiéis das classes médias, surge a umbanda, que, ao passo que busca a aproximação de concepções religiosas banto-sudestinas com o espiritismo kardecista europeu e com o catolicismo, também incorpora ao seu panteão os orixás do candomblé, ao lado de entidades espirituais advindas dos cultos banto, como os caboclos e pretos-velhos.

Paralelas, e mesmo em alguns casos anteriores à estruturação das religiões banto em formas autônomas de culto organizadas em espaços próprios, as rodas de jongo aparecem como lugares privilegiados de reunião entre africanos e afrodescendentes, sobretudo nas fazendas de cana e café do Sudeste, noticiadas a partir do século XIX. Cronistas destacam, justamente, o medo que tais encontros infundiam nos brancos, numa época em que se multiplicavam as rebeliões escravas:

Nas fazendas de Vassouras, RJ, as reuniões de cativos para a dança do Caxambú [Jongo] preocupavam os patrões. Os regulamentos municipais de 1831 e 1838, sob a pressão dos fazendeiros, procuraram coibir os encontros de "danças e candomblé", temendo que os negros "organizassem sociedades ocultas, aparentemente religiosas, mas sempre perigosas pela facilidade com que algum negro inteligente poderia utilizá-las para fins sinistros". ${ }^{45}$

Em movimentos sucessivos, vemos os jongos serem proibidos e em seguida autorizados pelas posturas municipais das cidades valeparaibanas, refletindo as tensas negociações entre patrões e escravizados, já no periodo final da escravidão, relativas ao binômio trabalho/lazer. Os jongos, como os demais batuques de terreiro tão

45 DIAS, Paulo. A outra festa negra. In: JANCSÓ, István; K ANTOR, Iris. (orgs.). Festa: cultura e sociabilidade festiva na América Portuguesa. São Paulo: Hucitec; Edusp, 2001, p. 863. Com citações de Stein, Stanley J. Vassouras, um município brasileiro do café, 1850-19oo, passim. 
temidos pelos brancos, eram tidos como "diversão desonesta" dos negros e triplamente condenados: na chave da segurança pública, pelo ajuntamento de escravizados que reunia, podendo incentivar a desordem ou a rebelião; na chave da moralidade, pela corporeidade considerada sensual de suas danças com ênfase no movimento de quadris e na umbigada; na chave da religião, por estarem associados acultos pagãos e à feitiçaria.

\section{Casa de reunião}

O ondjango, njango ou jango, lugar sociocultural central na vida comunitária das sociedades angolanas tradicionais (locus vitallis, no dizer de Kavaya) é, antes de tudo, casa de ekongelo (reunião). Trata-se de assembléia exclusivamente masculina; o ondjango parece radicar nas antigas sociedades secretas de homens. As mulheres cujos maridos se reúnem no ondjango intervêm apenas preparando a comida a ser partilhada entre todos. Nesse espaço são discutidos diferentes assuntos da comunidade através do diálogo de igual para igual, mediado por olosekulu (anciãos), valendo-se essa conversa de diferentes formas de enunciação: palavra cântico, palavra música, palavra provérbio.. Segundo Nunes apud Kavaya, o ondjango constitui-se em

...assembléia que se reunia em determinado local para conversar, discutir, tratar de todos os assuntos (...) a vários níveis: familiar, de bairro, de aldeia ou só de responsáveis. Quando se tratava de uma reunião geral dos homens, deve referir-se que ali era feito um controle diário de toda a vida e de todas as vidas, isto é, ali se conversava e ali se davam informações tanto de caráter publico como de caráter mais privado. [...]Digamos que se trazia, diariamente, o ponto de situação. E era um balanço da vida profundamente comunitário. ${ }^{46}$

Dependendo do assunto tratado, só os homens adultos e, por vezes, só os mais maduros podiam participar, sendo os jovens admitidos no ondjango em ocasiões especiais, como durante os ritos de iniciação.

46 KaVAYA, Martinho. Educação, cultura e cultura do "Amém”: diálogos do Ondjango com Freire em Ganda-Benguela/Angola, p. 149. 
No sentido de casa de ekongelo, sobressaem dois aspectos do jongo que mostram analogias com o ondjango. Em primeiro lugar, o terreiro festivo como lugar privilegiado do encontro, onde jongueiros que no dia-a-dia vivem geograficamente dispersos se agregam para celebrar, e só então o grupo assim formado se qualifica como comum-unidade. O segundo é o seu caráter masculino e adulto: até bem recentemente, mulheres e crianças eram proibidas de entrar no jongo, e mesmo de se aproximar das rodas. Segundo depoimentos ouvidos em diferentes comunidades, o jongo era constituído por uma confraria masculina, de faixa etária situada entre a maturidade e a velhice. São frequentes os relatos de que, quando crianças, os futuros jongueiros tentavam se achegar às rodas, para ouvir os pontos e conversas dos mais-velhos, no que eram prontamente repreendidos e castigados. Tornar-se jongueiro só era possível após longos anos de preparação, e por via da transmissão consanguínea, principalmente do pai, que acompanhava o filho nas rodas até que este estivesse capacitado a desviar sozinho das palavras-flecha desferidas pelos cumba (jongueiros fortes, conhecedores).

A jongueira Maria José Martins de Oliveira, a Dona Mazé, de Guaratinguetá-SP, fala sobre o sentido comunicacional coletivo atribuido ao jongo nos tempos da escravidão, sugerindo uma possível retraducão, na diáspora, de aspectos da instituição africana da fala coletivizada, restrita e amoldada aos modos, locais e tempos possiveis de reunião num contexto de aprisionamento e trabalhos forçados, de negação total de direitos do muntu ${ }^{47}$ :

Os escravos não podiam se comunicar com ninguém, eles não tinham liberdade. Então, quando eles entravam na senzala é que eles iam participar um com o outro. Então, no meio eles faziam a roda de Jongo e, ali, cada um cantava o Jongo falando o que queria falar, pela canção. Daí, um entendia o que tinha que serfeito. As vezes o que se passou no dia, o que ia acontecer. Então, um já avisava o outro. E, era por meio de ponto de Jongo que eram comunicadas as coisas. ${ }^{48}$

47 O temo banto muntu, singular de bantu, designa o "existente inteligente", ou seja, a pessoa humana.

48 Registro do Acervo da Associação Cultural Cachuera! 
O ponto de jongo, por ter um falar e dois entender ${ }^{49}$ ou seja, diferentes articulações de sentido para os de dentro e os de fora da roda, revestiu-se de papel estratégico durante o período da escravidão, como linguagem críptica acionada entre cativos; isso fica evidente no depoimento de Dona Mazé - "Daí, um entendia o que tinha que ser feito... Então, um já avisava o outro". Aquelas canções, inócuas aos ouvidos leigos, traziam ocultas mensagens de fundamental importância para a comunidade cativa, firmando-se como ferramenta de resistência às severas restrições comunicacionais da escravidão ${ }^{50}$.

O historiador estadunidense Stanley Stein, um dos poucos a registrar depoimentos de ex-escravizados sobre o jongo do tempo do cativeiro, também destaca o papel do canto dialogado metafórico trocado entre escravizados que trabalham no eito, como vetor de comunicação e articulação entre eles: “As notícias[...] circulavam sutilmente disfarçadas em versos enigmáticos de jongo cantados por grupos de fazendas vizinhas, enquanto trabalhavam nas encostas de café". ${ }^{51} \mathrm{O}$ uso da linguagem figurada e simbólica nas culturas africanas e afro-descendentes, e especificamente nas suas formas literárias, será tratado mais adiante.

\section{Mediação de anciãos, presença de ancestrais}

Segundo Nunes apud Kavaya, na assembléia do onjango "Agrupados todos os homens à volta do sekulu, do chefe 'mais-velho', era este quem servia de oficiante ao ritual das perguntas". ${ }^{52}$ Martinho Kavaya esclarece os sentidos de osekulu no ondjango:

No ondjango não existe quem saiba mais, e sim existe quem tem mais experiência vital. Este partilha suas experiências, mas é também aberto ao novo com os membros do ondjango. É de salientar que quem tem experiência é detentor da última

49 Segundo explicação do jongueiro Jeferson Alves de Oliveira, o Jefinho de Guaratinguetá - SP.

5o Por isso até hoje se canta no jongo: "Vovó não quer /casca de coco no terreiro/porque lhe faz lembrar/os tempos do cativeiro". Casca de coco refere-se, no contexto da festa sempre vigiada, ao indivíduo externo ao grupo que se aproxima da roda, na intenção de decifrar seus códigos. A interpretação desse ponto deve-se ao teólogo Gilberto de Exu.

51 STEIN, Stanley J. Vassouras, um município brasileiro do café, 1850-1900, p. 244.

$5^{2}$ KAVAYA, Martinho. Educação, cultura e cultura do "Amém": diálogos do Ondjango com Freire em Ganda-Benguela/Angola, p. 149. 
palavra no ondjango. Quer dizer, a ele se dá a oportunidade de abrir e fechar o ondjango ${ }^{53}$ [...] Olosekulu, nesse caso, não são, somente, pessoas de idade avançada, como, também, pode ser uma pessoa mais nova com experiência de vida. ${ }^{54}$

A partir de relatos de ex-escravos, Stein descreve o jongo do cativeiro:

Depois que as tarefas estivessem terminadas, acendia-se a lenha empilhada no terreiro de secagem. Um casal de tambores[...] ocupava um lado a fogueira; no outro sentavam-se negros idosos, geralmente africanos, chamados por um ex-escravo de macota ("pessoas da Africa, pessoas sábias"). ${ }^{55}$

Acrescenta que, nas rodas de então, havia a figura do rei do caxambu, por vezes acompanhado de uma rainha, cuja função era de abrir o jongo e zelar pelo bom andamento do evento, apaziguando as disputas demasiado ferrenhas: “[...] se aparecesse algum problema entre os versejadores que se contestavam, o rei retornava imediatamente e silenciava os tambores colocando suas mãos sobre eles". ${ }^{56}$

Assentados em lugar de honra ao lado do fogo (que simboliza a presença dos ancestrais, conforme veremos adiante), de onde podiam supervisionar o desenrolar do jongo, os macota, definidos como velhos africanos sábios por um ex-escravo, representam possível reminiscência dos olosekulu, anciãos que presidiam os olondjango angolanos, com presença estrutural na condução das conversas, na transmissão do conhecimento ancestral e na mediação de conflitos. Os chamados rei e rainha do jongo, termos que sugerem autoridade sobre os demais participantes, podem igualmente estar associados ao sekulu que, graças à sua experiência vivencial, está capacitado a zelar pela correta ritualidade do encontro e pelas boas relações entre os interlocutores, ou, ainda, aos olosoma, chefes tradicionais, figuras de autoridade nas sociedades ancestrais angolanas que desempenhavam igualmente o papel de juizes e de mediadores nas discussões e nos julgamentos que tinham lugar nos olondjango.

53 Os jongueiros obedecem a princípios semelhantes de hierarquia por senioridade existencial, uma vez que que o privilégio de abrir e fechar o jongo através de pontos e saravações compete ao jongueiro mais experiente do grupo.

54 KAVAYA, Martinho. Educação, cultura e cultura do "Amém": diálogos do Ondjango com Freire em Ganda-Benguela/Angola, p. 150.

55 STEIN, Stanley J. Vassouras, um município brasileiro do café, 1850-1900, p. 244.

56 STEIN, Stanley J. Vassouras, um município brasileiro do café, 1850-19oo, p. 246. 
Um dos aspectos fundantes da religiosidade banto é o culto aos ancestrais da família, do clã ou do grupo, conforme observaram autores como Placide Tempels. A cadeia de ancestralidade assegura o vínculo do indivíduo vivente com o criador pré-existente, sendo a força vital dos antepassados hierarquicamente superior a dos viventes por sua maior proximidade com a divindade primordial ${ }^{57}$. A presença espiritual dos ancestrais é constantemente solicitada entre os viventes, a fim de orientar-lhes os passos na terra com seu acúmulo de experiência existencial. O elo com os ancestrais é estabelecido nas práticas rituais, onde eles podem se presentificar através da incorporação, ou por intermédio de diferentes canais simbólicos que se abrem no mundo físico; um deles é o fogo.

No ondjango, a fogueira é elemento central, sendo mantida permanentemente acesa graças às pilhas de lenha trazidas pelos mais jovens ao recinto da reunião. Entre diferentes povos banto, o fogo e a fumaça têm sentido de mediadores na comunicação entre o mundo dos viventes e o dos ancestrais. Nas casas dos ovimbundo, um fogo permanece sempre aceso, simbolizando a continuidade da autoridade do soba (chefe político) e de sua linhagem de ancestralidade; quando este morre, os fogos devem ser apagados, e reacesos com a eleição de um novo chefe. Do fogo central aceso pela mão do soba recém-eleito são retiradas brasas com as quais se acenderão fogos nos lares dos seus súditos, como forma de reafirmar os laços com os antepassados do grupo ${ }^{58}$.

Nas comunidades jongueiras, assim como em outros batuques ancestrais de origem banto, a roda de dança é organizada obrigatoriamente ao lado ou em torno de uma fogueira. No jongo do Tamandaré, em Guaratinguetá-SP, a importância atribuída à fogueira se traduz na existência de um cargo específico, na estrutura do festejo,para a pessoa responsável por juntar lenha, transportá-la, organizar e acender a fogueira: trata-se do capitão da fogueira. A força do fogo como orientador de espíritos ancestrais é destacada por Dona Mazé, de Guaratinguetá:

A fogueira é pra esquentar os tambores e para dar mais luz aos espíritos que vêm nos ajudar. Porque numa roda de jongo aparecem muitos jongueiros, e aqueles jongueiros vêm com força, com luz, para nos orientar, para nos dar forca, para

57 TEMPELS, Placide. La philosophie bantoue. Paris: Presence Africaine, 1949.

58 SLENES, Robert W. Na senzala, uma flor, p. 241, com base em FIGUEIRA, Luiz. Africa Bantú: raças e tribos de Angola. Lisboa: Oficinas Fernandes, 1938. 
nos guardar. Nunca se abre uma roda de jongo sem saravar os jongueiros velhos. Eles que nos protegem, que nos ajudam, que vão junto da gente. ${ }^{59}$

A presença espiritual dos ancestrais, assegurada pela fogueira sempre acesa, é vital para o correto desenrolar do ritual jongueiro, pois acredita-se que esses espíritos dão guarida e conselhos aos viventes que participam da roda. Na abertura do jongo, os ancestrais jongueiros devem ser homenageados com libações propiciatórias de cachaça, derramada na fogueira e sobre as peles dos tambores, e saudados em primeiro lugar na roda.

\section{Pontos, provérbios, adivinhas}

Para orientar os diálogos no onjango, o sekulu amiude se vale da sabedoria ancestral plasmada em multiplos gêneros da literatura oral.

As lendas, as fábulas, os contos, os provérbios, as adivinhas, os aforismos, as sentenças, as narrações históricas, as orações, as invocações, as bençãos, as maldições, as fórmulas mágicas, as récitas de adivinhações, os juramentos, as fórmulas propiciatórias e de ações de graças e os cantos fazem parte deste leque da tradição africana. Essa tradição pode ser narrada ou cantada. Há casos que as narrações são intercaladas pelos cânticos. ${ }^{60}$

Particularmente importantes na transmissão do conhecimento acumulado pelo grupo sobre diferentes aspectos da vida em sociedade, os provérbios são de uso frequente nos olondjango. Segundo a especialista em tradições orais Ruth Finnegan, eles recorrem abundantemente por quase toda a África, tendo como principais características a extrema concisão, a justeza de apreensão de sentido e a sutil utilização de linguagem figurada, alusiva às mais diversas

59 Depoimento constante do filme de XAVIER, Rubens (Dir.). Feiticeiros da Palavra (Associação Cultural Cachuera!/TV Cultura, 2001). Saravar jongueiro velho significa saudar os jongueiros já falecidos, espirituais (como no termo umbandista pretos velhos).

6 o Altuna, Pe. Raul de Assua. Cultura Tradicional Bantu, p. 38 . 
situações existenciais. Com forma relativamente fixa, expressam verdades de ampla aceitação no interior do grupo cultural ${ }^{61}$.

Enquanto casa de elongiso/okulonga (educação/iniciação), o ondjango é, por excelência, o lugar de aprendizado dos valores socioculturais, das regras de existência comunitária, do trato com o sagrado. Muitos dos assuntos e ensinamentos do okulonga são de ordem secreta e iniciática e não podem ser divulgados pelos participantes fora do ondjango. Geraldo Amandio Ngunga fala do potencial formador dos provérbios no ondjango:

Ai ele [sekulu] destilou toda a sua sabedoria e acumulou o pensamento e reflexão de milhares de anos (...). Com os provérbios aprendidos no ondjango, o homem bantu reforça seus argumentos filosóficos seja para solucionar um conflito, como para ensinar sábias sentenças, ou moralidade tirada de uma historia, e com a variedade de suas imagens comunicam-se os encantos poéticos, estéticos e morais [...]. ${ }^{62}$

Outro gênero da literatura oral empregado nos olondjango para estimular a perspicácia e a inteligência dos jovens aprendizes é a adivinha. Como os provérbios, são de enunciação rápida e concisa, encerrando analogias de sentido, som, ritmo ou tom ${ }^{63}$. Apresentam-se como enigmas a serem resolvidos, devendo-se para isso identificar o referente aludido na metáfora ou símile - possuem, portanto, dois momentos, a apresentação da questão e sua resposta ${ }^{64}$. Diferentemente dos provérbios, utilizados em ocasiões mais sérias, as adivinhas estão associadas ao universo do entretenimento infanto-juvenil, sendo seu contexto habitual os eventos competitivos ${ }^{65}$. Ao enumerar

61 FINNEGAN, Ruth. Oral Literature in Africa. Cambridge, UK: Open Book Publishers, 2012, p. 383. DOI: 10.11647/OBP.00252012

62 Depoimento colhido por KAVAYA, Martinho. Educação, cultura e cultura do “Amém”: diálogos do Ondjango com Freire em Ganda-Benguela/Angola, p. 151-152.

63 Grande parte das línguas africanas é tonal, isto é, a entonação (baixa, média, alta) das palavras pode determinar seu sentido. Os tons são utilizados esteticamente em gêneros como provérbios e adivinhas, através, por exemplo, de paralelismos e analogias entre termos com idêntica entonação.

64. Segundo Finnegan, nas adivinhas africanas, a seção que contém a alusão metafórica nunca é expressa como interrogação (do tipo “o que é, o que é?”), mas como afirmação, tal como ocorre nos pontos de jongo (demanda), conforme se verá adiante.

65 FINNEGAN, Ruth. Oral Literature in Africa, p. 413. 
as categorias da literatura oral africana, Hampaté Bâ lista tanto os provérbios quanto as adivinhas sob a rubrica "textos didáticos". ${ }^{66}$

Segundo Finnegam, em diferentes culturas africanas há estreita conexão entre adivinhas e provérbios, sendo os dois gêneros com frequência realizados de maneira articulada, explicitamente ou por alusão. Entre povos banto da África Central, por exemplo, a consagrada adivinha "Uma coisa que eu lanço para o outro lado do rio - os olhos", lembra um provérbio igualmente comum: "Os olhos cruzam um rio inteiro", significando metaforicamente que o desejo pode ir além do possível. Existem, ainda, formas híbridas, os provérbios-adivinha ${ }^{67}$.

Em seu ensaio "Raízes de Tradições Orais em Romances Históricos Angolanos", a socióloga Ana Lúcia Sá, ao comentar o conto "O Feitiço da Rama de Abóbora", do autor angolano ovimbundo Tchikakata Balundu ${ }^{68}$, nos leva a acompanhar o jovem personagem Cisoka resolvendo adivinhas propostas por um sekulu, após o repasto comunitário no ondjango:

Depois da refeição, inicia-se uma sessão de adivinhas, introduzida por um velho com a expressão "Alupolo?" ("Vai uma adivinha?"), ao que se responde em coro "Luiye!" ("Venha, venha!"). A primeira é "As águas vão, mas a areia fica”.Segundo a tradição, uma maior consideração na aldeia por parte dos participantes depende do número de adivinhas acertadas. Nesta sessão, é importante que Cisoka adivinhe para recuperar o seu prestígio. É ele quem dá a primeira resposta: "Somos nós, os homens (...), desaparecemos ao morrer, mas os nossos nomes ficam e podem ser atribuídos aos que nascem depois de nós". A segunda interpelação do sekulu Mango é "Tronco queimado não se reduz a cinzas", que causa agitação nos jovens e que leva novamente Cisoka a responder em primeiro lugar, "quando morremos somos enterrados... ou melhor, ninguém faz falta neste mundo". ${ }^{69}$

66 HAMPATÉ BÂ, A. Aspetti della civiltá africana, Nigrizia. Bologna, 1975, p. 88. O autor reconhece entre as tradições literárias orais da África as seguintes categorias: fórmulas rituais, textos didáticos, histórias etiológicas, contos populares, mitos, récitas, poesia variada, poesia oficial, narrações históricas.

67 HAMPATÉ BÂ, A. Aspetti della civiltá africana, Nigrizia, p. 418.

68 BALUNDU, Tchikakata. O Feitiço da Rama de Abóbora. Porto: Campo das Letras, 1996.

69 SÁ, Ana Lúcia Lopes de. Raízes de tradições orais em romances históricos angolanos, p. 149. 
Ao que tudo indica, os modos de enunciação destacados por Kavaya no ondjango - palavra cântico, palavra música, palavra provérbio, associados à veiculação de formas condensadas da literatura oral, estão na base das formulações cantopoéticas jongueiras. Nas rodas de jongo, a conversa entabulada entre jongueiros faz uso combinado dessa trilogia; suas unidades poetico-melódicas são poemas-cânticos caracterizados pela estrutura sintética e pela formulação em sentido figurado ou simbólico - os pontos ${ }^{70}$.

Segundo Ruth Finnegan,

Em muitas culturas africanas, um talento inato para a linguagem, para as imagens e para a expressão de idéias abstratas através de fraseologia comprimida e alusiva manifesta-se de maneira especial nos provérbios. A qualidade figurativa dos provérbios é particularmente marcante; uma das suas características mais notáveis é o estilo alusivo, usualmente em forma metafórica. Essas características também transparecem em muitos dos termos nativos traduzidos como "provérbio" que frequentemente enfatizam primordialmente o sentido de falar em termos simbólicos.

[...] a palavra Kamba ndimo não correspode exatamente ao nosso termo "provérbio", mas é um equivalente próximo; na realidade, significa "fala obscura" ou "fraseado metafórico", um tipo de linguagem secreta e alusiva. ${ }^{71}$

Com forma e formulação imagética muito próximas às do provérbio e da adivinha africanos, os pontos tradicionais do jongo são curtos e densamente significantes ${ }^{72}$, aludindo metaforicamente a diferentes situações ou contextos, cujos referentes são normalmente conhecidos ao menos de uma parte dos participantes; nesse sentido, o jongo assume características semelhantes às da "linguagem secreta" citada por Finnegan, importante na construçãoda identidade jongueira do grupo. Em sua versão mais sintética, os pontos podem ter apenas dois versos (os chamados de uma volta), um entoado pelo

70 Também no candombe mineiro, como na umbanda, os cânticos são assim chamados; em outras tradições banto-brasileiras como o congado, cantar ponto é servirse de fórmulas orais com poder de mobilizar forças espirituais.

71 FINNEGAN, Ruth. Oral Literature in Africa, p. 380. (Tradução nossa)

72 O jongo atual se distancia da forma sintética e conotada e tende a adotar uma versificação mais abundante e descritiva, próxima da canção popular. Sobre esse assunto, ver DIAS, Paulo. Tradição e Modernidade nas Ingomas do Sudeste. Anais do II Encontro de Culturas e Diásporas Africanas. Juiz de Fora: UFJF, 2009. 
jongueiro e outro respondido em coro pelos participantes, sendo acompanhado dos tambores tambu e candongueiro e de palmas, e interagindo em simultaneidade com a dança.

No jongo tradicional, os pontos cantados são, por vezes, precedidos por partes faladas ou recitadas pelos jongueiros; por exemplo, na ocasião em que eles cantam pela primeira vez na roda ${ }^{73}$. Ao fazer sua saravação (saudação), o jongueiro pede licença - aos tambores, à natureza sacralizada ("Viva a terra que come nós e dá pra nós!") ${ }^{74}$, ao mundo espiritual, aos jongueiros (chamados de galos) falecidos e viventes e a todos os presentes - assumindo sua elocução a forma de um recitativo falado ou monotonal (ou canto-falado, entoado sobre uma única nota em tempo livre). Em algumas comunidades, como S. Luis do Paraitinga - SP e Santo Antônio de Pádua - RJ, tive a oportunidade de ouvir sequências em que se alternavam recitativos em canto falado, em que o jongueiro introduz o assunto do ponto, e os pontos propriamente ditos, cantados ritmicamente ao som dos tambores, quando se estabelece o modo responsorial (alternância solo-coro, com partes específicas para cada um) e se inicia a dança. A alternância do canto-falado e do ponto responsorial ritmicamente executado caracteriza a performance do candombe mineiro.

Ruth Finnegan chama atenção para os limites por vezes tênues que separam os gêneros da literatura oral africana de outras formas de expressão como a música e a dança; frequentemente os poemas épicos podem ser expressos na forma de canções, com acompanhamento de instrumentos, sendo os refrões ou coros de resposta assumidos pelos circunstantes. Na performance de um texto literário, o artista pode lançar mão de elementos expressivos como mímica e movimentação corporal, e até mesmo da dança, "frequentemente incorporando membros da platéia (ou coro)". ${ }^{75}$ A autora presenciou um julgamento tradicional Mbala no Congo, durante o qual as falas dos oradores das partes rivais eram entremeadas com cantos alegóricos ao som de um tambor ${ }^{76}$. A estrita definição de fronteiras entre o literário, o musical e coreográfico com frequência não faz sentido nas culturas africanas tradicionais, onde elocuções expressivas de diferentes naturezas podem incluir uma complexa imbricação de meios (os quais, nas culturas ocidentais, são pensados como "artes autônomas").

73 Procedimento atualmente em declínio.

74. Mestre Joviano, São Luis do Paraitinga. Registro do CD Batuques do Sudeste.

75 FINNEGAN, Ruth. Oral Literature in Africa, p. 7.

76 FINNEGAN, Ruth. Oral Literature in Africa, p. $43^{2}$. 
A comparação, em termos da forma, estilo e conteudo simbólico, de alguns pontos de jongo com os provérbios e as adivinhas africanos, particularmente as do povo ovimbundo, revelou interessantes analogias. Um ponto muito antigo, clássico (diz-se que é do tempo do cativeiro), recorrente em quase todas as comunidades jongueiras que conheço, diz o seguinte:

\section{Tanto pau no mato/embauva coroné}

Na metáfora expressa no ponto, o senhor de escravos, coroné, é uma embauva, árvore oca, podre por dentro, sendo que no mato, a sociedade humana, não falta pau de madeira de lei - ou seja, homens íntegros. No ponto de jongo acima citado, bem como na segunda adivinha proposta pelo sekulu Mango no conto de Tchikaka Balundu (tronco queimado não se reduz a cinzas), a árvore é utilizada como imagemmetafórica do ser humano. A coleta realizada pelo Padre José Francisco Valente em Bié, Huambo e Benguela, no Centro-Sul de Angola revela que essa associação simbólica é frequente nos provérbios ovimbundo:

Uti ulivondela ofela kawuteki (árvore que se inclina ao vento não parte $=$ o homem deve estar atento ao rumo dos acontecimentos na sociedade em que vive)

Oviti vyalikunana ovyo vyokuliseka (árvores de madeira de lei que se vergam também se esfregam = até mesmo os homens de caráter entram em atrito. ${ }^{77}$

Outro fator relevante para nossa aproximação entre pontos de jongo e provérbios africanos é o aspecto situacional de ambos. O que Ruth Finnegan observa em relação aos provérbios é perfeitamente aplicável aos pontos:

Provérbios são usados em ocasiões particulares, por indivíduos inseridos em contextos específicos, e sua sagacidade, seu poder de sedução, sua capacidade de penetrar a natureza íntima de uma coisa, e mesmo o seu significado devem ser considerados como emanando desse contexto. ${ }^{78}$

77 VAlente, Pe. José Francisco. Seleção de provérbios e adivinhas em umbundu. Luanda: Junta de Investigações do Ultramar, 1964. P. 178-179.

78 FINNEGAN, Ruth. Oral Literature in Africa, p. 411. 
Nesse sentido, seja colorindo as conversas do dia a dia, seja coroando a retórica dos grandes discursos públicos, a enunciação de provérbios que resumem certeiramente situações expressas na fala é muito apreciada nas sociedades africanas da oralidade, indicando senso de oportunidade, estilo e eloquência do orador, motivo de prestígio e admiração.

No jongo se valoriza sobremaneira o intérprete que sabe tirar partido de uma situação ou de um acontecimento recente de seu grupo social, utilizando-o secretamente como referente na construção metafórica de seu ponto. Para isso, o jongueiro lança mão de novas elaborações, construídas a partir de um vocabulário crítico conhecido do grupo, ou da ressignificação de enunciados buscados na tradição, cuja formulação simbólica abstrata e hermética se mostra propícia à produção de diferentes interpretações. Finnegan afirma que os provérbios podem adquirir sentidos diferenciados conforme a circunstância em que são emitidos ${ }^{79}$; essa dimensão circunstancial cabe perfeitamente ao fazer jongueiro, sendo que a interpretação ou chave simbólica de um ponto com conteudo textual fixado pela tradição pode variar de acordo com a situação específica em que é cantado $^{80}$. Talvez seja este um dos motivos por que, nas rodas de jongo, a forma proverbial africana tenha se fixado como a mais competente para a comunicação intra-grupal: no contexto do escravismo, própria para se adaptar à veiculação de mensagens em diferentes situações, e colorindo-se, como camaleão (metáfora jongueira para negro), de acordo com o ambiente; e obscura o suficiente para não provocar suspeitas aos ouvidos da gente de fora (casca de coco, na metáfora jongueira).

Entre as adivinhas umbundo, também encontramos similaridades com os pontos de jongo. Ao compararmos a primeira adivinha desvendada pelo personagem Cisoka durante a sessão no ondjango, no conto "O Feitiço da Rama de Abóbora", a um ponto de jongo registrado em Cunha, nos vemos em presença de construções simbólicas idênticas - inclusive em relação à chave interpretativa (no jongo

79 FINNEGAN, Ruth. Oral Literature in Africa, p. 403.

80 Embora clássico no meio jongueiro, o ponto da embauva acima citado foi interpretado de maneira diferente por Toninho Canecão, líder da comunidade jongueira do Quilombo São José da Serra: para martirizar um escravo, o patrão deu a ele a frágil madeira de embauva para que construísse sua morada; com sabedoria, o escravo sapecou a embauva no fogo, tornando-a resistente, e utilizou-a na construção da casa, inclusive da viga-mestra, chamada localmente de "coroné". 
denominada desate), que alude ao tema da permanência das realizações do ser humano face à efemeridade de sua existência:

As águas vão, mas a areia fica (adivinha umbundo) Agua passa por cima, areia fica no lugar (jongo de Cunha) ${ }^{81}$

Temos aqui indícios da resistência de algumas dessas construcões imagéticas banto-africanas em seu percurso diaspórico. Como já foi mencionado, no contexto de uma sociedade hostil, que mesmo após a Abolição permanece excludente e racista, a linguagem figurada da poética jongueira, irrigada por provérbios e adivinhas banto, tende a assumir sentidos de resguardo, assegurando, sob sua dubiedade desorientadora, a transmissão de mensagens do dia-a-dia, de saberes ancestrais, de pricipios religiosos, éticos e morais africanos.

\section{Categorias dialógicas no jongo e no ondjango}

O espaço do ondjango se presta a diferentes tipos de reunião, segundo as necessidades da vida social, cada um deles com códigos de conduta, modos de interlocução e configurações discursivas próprios. No caso do jongo, os pontos cantados são normalmente identificados pelos praticantes como pertencentes a categorias distintas, relacionadas a situações comunicacionais específicas ou tipos de intervenção/interação do jongueiro na roda.

No jongo, a categoria louvação refere-se aos pontos cantados para abrirefechar o jongo, render homenagem a ancestrais jongueiros e pessoas importantes, colocar situações existenciais ou marcar momentos ritualmente importantes da roda. Buscando correspondência no ondjango angolano, deparamo-nos com a categoria ulonga (relato dialógico). Para Geraldo Amândio Ngunga,

O Ulonga é um relato que resume os acontecimentos vividos desde o espaco temporal em que o visitado e o visitante se viram, até o novo reencontro. É um momento de empatia entre

81 A forma completa desse ponto é: "água com areia/nunca pôde combinar/água passa por cima/areia fica no lugar", sendo que os dois primeiros versos são cantados só na introdução; quando entram os tambores e se estabelece o jogo reponsorial só se cantam os dois últimos versos (ou seja, o dístico do ponto propriamente dito, dividido entre solo e coro). Também pode ser interpretado como o autoelogio de um jongueiro que, por seu conhecimento, deixa sua marca na roda de jongo (areia), enquanto seu rival, que não tem essa competência, não será lembrado (água). 
dois sujeitos que juntos vivem o passado no presente, alegre ou triste da vida. ${ }^{82}$

Há diferentes fases no ulonga: 1) saudação e justificativa do encontro; 2) narrativas dos momentos mais importantes das vidas dos interlocutores desde o último momento em que estiveram juntos, pontuadas por manifestações dos participantes 3) recapitulação de assuntos de maior relevo na conversa, a serem retomados em futura ulonga, saudação dos participantes e abertura da assembléia para outros assuntos.

Os pontos de louvação são emitidos na roda para saudar respeitosamente pessoas e entidades espirituais, muitas vezes em tom de elogio (como os praise-songs dos banto meridionais citados por Finnegam). Além das saudações elogiosas a outras pessoas, a louvação inclui o falar de si, ou seja, a alusão a etapas importantes da vida recente de quem canta, a passagens difíceis de sua existência e a superação destas, compartilhando-se no foro coletivo as experiências individuais - prática tipicamente onjanguiana. A presença dessas duas formas distintas de interlocução (saudação e autorreferência) indica similaridade, nos planos ritual e textual, entre a modalidade jongueira da louvação e a onjanguiana do ulonga (correspondendo às suas etapas 1 e 2). Abaixo, dois exemplos de pontos de louvação com conteúdo de autorreferência tirados do cancioneiro do Jongo do Tamandaré, em Guaratinguetá-SP:

Oi Tambu/quando eu for embora pra bem longeleu levo comigo/ esse som que bate forte/em meu coração - Ponto cantado pelo jongueiro Totonho (Antônio Marcondes Filho) para marcar afetivamente sua partida para outra cidade;

Bate bate coração, pode bater/não treme não, ai coração, para de tremer/bate bate coração / que a nossa vida já tem solução, viva São João - Ponto de Dona Tó (Antônia Rita Jeremias), em que a jongueira participa aos presentes o fato de ter atravessado com coragem grandes provações em sua vida e ter saído vitoriosa.

Já a categoria de pontos identificada como visaria é voltada à crônica social, e com eles se comentam assuntos recentes da

82 Depoimento registrado por KAVAYA, Martinho. Educação, cultura e cultura do "Amém": diálogos do Ondjango com Freire em Ganda-Benguela/Angola, p. 152. 
comunidade ou se tecem considerações sobre seus personagens (falar dos outros), muitas vezes de maneira jocosa ou irônica, suscitando pronta resposta da pessoa visada. O estilo mais leve, descomprometido e por vezes anedótico dos pontos de visaria nos permite uma comparação com a prática do ombangulo (conversa) no ondjango angolano, uma conversa entre amigos, mais casual e menos séria e codificada que o ulonga, em que a palavra colore temas variados do grupo, num diálogo vivo e acalorado onde cada um, com sua fala, se esmera em comover de alguma forma os interlocutores, incentivando respostas e reflexões. Como exemplo de visaria, citamos um ponto humorístico dirigido a um jongueiro do Tamandaré que tinha fama de conquistador, e a todo instante se apartava da roda de jongo em busca de companhia feminina:

É de Laura/é de Laurita/prende a Laura/solta a Rita

A resposta do jongueiro foi:

Quero me levantar na primeira cantará do galo/eu quero subir no trono/acordar a primaceia/que está no primeiro sono

Alertando que, apesar de namorador, ele "não estava dormindo" e permanecia bem atento ao jongo ${ }^{83}$. Lembremos aqui o frequente uso da ironia notado por Finnegan nos provérbios africanos, bem como o parentesco destes com os gêneros anedóticos da literatura oral:

Chatelain apontou que os provérbios ambundo tem uma forte relação de proximidade com as anedotas, tanto é que as anedotas são por vezes apenas ilustrações de um provérbio, enquanto um provérbio é com frequência uma anedota em tamanho reduzido. ${ }^{84}$

Uma terceira categoria é constituída pelos pontos ditos de demanda ou goromenta, destinadosa entabular debate sobre determinado asunto, ou então a formular/responder a enigmas ou adivinhas, à maneira de um desafio. Nesta categoria, os pontos considerados

83 A interpretação é do jongueiro Antônio Marcondes Filho, o Totonho do Tamandaré. Cf. KISHIMOTO, Alexandre; TrONCARELLI, Maria Cristina; DIAS, Paulo (orgs.) O Jongo do Tamandaré. Guaratinguetá - SP. São Paulo: Associação Cultural Cachuera!, 2012. p. 120.

84. FINNEGAN, Ruth. Oral Literature in Africa., p. 21. 
mais fortes são aqueles mais difíceis de entender, talhados em linguagem figurada hermética. São muitas as histórias acerca de ferozes duelos de palavras no jongo, em que um jongueiro de fora vem disputar prestígio na roda do bairro através de seus pontos cheios de malícia $^{85}$. O conhecimento das palavras ancestrais e seu significado simbólico e místico, objeto de grande segredo entre jongueiros, é que define o cumba, o sábio, e o capacita a sair vencedor nas demandas. O poder de realização dos pontos de demanda vai além de simplesmente desmoralizar o oponente que não souber desatá-los (encontrar a chave do enigma); segundo se crê, nesse caso o jongueiro pode ficar amarrado, isto é, paralizado, sem ação, por artes da força contida das palavras. Diz-se que os antigos cumba faziam crescer bananeiras nos terreiros de jongo apenas com sua cantoria, sendo que ao raiar do dia já havia banana madura pra todo mundo comer.

Entre os bantu, a fala é concebida como dinamizadora de forças vitais e, se convenientemente utilizada, pode intervir no mundo físico, modificando sua ordem. Em umbundo há uma expressão que diz undaka usongo, ou seja , a palavra é uma flecha, podendo matar ou salvar. No jongo, conforme apontamos em estudos anteriores ${ }^{86}$, subsiste o princípio africano da palavra que atinge, da palavra que move, da palavra-flecha com a qual se deve ter máximo cuidado, sempre procurando esquivar-se dela ao mesmo tempo em que se arremessa ao oponente outra com gume igualmente afiado.

A prática das justas de enigmas ou adivinhas foi notada em Angola por diversos autores, entre eles o escritor português Ladislau Batalha ${ }^{87}$, já no final do século XIX: "Passam os filhos de Angola noites inteiras ao pé do lume, fumando ao ar livre os seus cachimbos. Cada um propõe a sua adivinhação, e aquele que a decifra responde". ${ }^{88}$

Ruth Finnegan aponta que a situação típica de enunciação de adivinhas na África é à noite, quando as crianças se encontram reunidas em torno de uma fogueira, como prelúdio à narrativa de histórias mais sérias pelos mais velhos. Outro contexto característico

85 A informação é de Totonho do Tamandaré.

86 DIAS, Paulo. A outra festa negra. IDEM. Jongo e Candombe, primos-irmãos: estudo comparativo de duas tradições banto-brasileiras do Sudeste . Ver também: MONTEIRO, Marianna. F. T; DIAS, Paulo. Os fios da trama: grandes temas da música popular tradicional brasileira. Estudos Avançados, São Paulo, v.24, n.69, p. 349-71, jan./abr. 2010. DOI: http://dx.doi.org/10.1590/eav.v24i69.10530

87 Cf. BATALHA, Ladislau. Costumes Angolenses. Lisboa: Companhia Nacional Editora, 1890 .

88 CARnEIRO, E. Samba de Umbigada. Rio de Janeiro: Campanha de Defesa do Folclore Brasileiro, 1961, p. 11. 
são as competições de adivinhas, estabelecidas entre indivíduos jovens ou equipes, particularmente notados na África banto. Podem ocorrer também, embora com menor frequência, competições de provérbios $^{89}$.

Esse tipo de desafio, em que os conhecimentos em torno da sabedoria ancestral detidos pelos contendores são postos à prova diante da coletividade reunida em instâncias de interlocução comunal como o ondjango, angariando os vencedores a admiração da comunidade e aumento de seu prestígio pessoal (como no caso retratado no conto de Tchikakata Bailundu) parece ter inspirado a categoria jongueira da demanda. Nos pontos pertencentes a essa categoria, também denominada goromenta (corruptela de "argumento"), podemos, eventualmente, detectar articulações simbólicas correlatas às adivinhas ovimbundo, como no exemplo abaixo:

Adivinha ovimbundo:

Ngasi k'omunda ndinhanhumula ochifuto (Estou na montanha e desdobro um lenço). Resposta: o nevoeiro.

Ponto de demanda do jongo de Guaratinguetá:

Comprei um lencol/que custou sete milhão/cobriu sete cidades/ arrastou ponta no chão.

Desate: Cerração nasce na serra/ e morre na beira d 'água. ${ }^{90}$

Note-se que, na demanda do jongo, o ponto contendo o enigma deve ser respondido por outro ponto, em que se revela sutilmente o desate.

Não obstante a conexão em termos do contexto da performance (desafio ou competição) e das formas literárias (adivinhas/provérbios), há uma divergência fundamental, que, provavelmente, se deve em grande medida à requalificação dessa atividade na diáspora: no caso africano estamos diante de uma alegre competição entre crianças, enquanto no brasileiro a disputa sempre foi entre adultos mais velhos, que medem seus conhecimentos em dramáticos e conflituosos embates.

Como observa Ruth Finnegan, uma das vocações mais notáveis dos provérbios na África é a de atenuar situações de conflito:

89 FINNEGAN, Ruth. Oral Literature in Africa, p. 425.

9o O desate deste ponto foi dado pelo jongueiro Zé Carlos, que o herdou do pai, Dito Prudente. 
Embora os provérbios africanos possam ocorrer em uma diversidade de contextos, o seu uso mais importante se dá nas situações em que há conflito, e ao mesmo tempo se procura evitar que esse conflito tome uma dimensão muito aberta e pessoal, explodindo em confronto explícito. Nesse contexto, percebemos o quanto é adequada a utilização da linguagem velada e metafórica dos provérbios. ${ }^{91}$

Essa propriedade da linguagem alusiva/simbólica de resguardar as pessoas, sob o seu manto de dubiedade, de implicações diretas em situações-limite, autoriza-nos a pensar que o seu uso entre jongueiros também pode estar relacionado, num primeiro momento, à necessidade de se amenizar tensões surgidas no interior do grupo, nas ocasiões em que se reuniam em olondjango improvisados nos terreiros e senzalas das fazendas onde serviam como escravos. Com o passar do tempo, é lícito imaginar que essa aplicação apaziguadora da metáfora, entre indivíduos colocados sob o jugo comum da escravidão, tenha-se rarefeito nas rodas de jongo, sobretudo já sob o impacto da Abolição e da consequente necessidade de afirmação e ocupação de lugares sociais entre os negros, em resposta à repentina marginalização a que se viram submetidos. Nesse contexto, a prática da fala simbólica e velada possivelmente tende a se concentrar nas competições por prestígio (demandas).

Entre os ovimbundo, os olondjango ditos de ekanga se prestam à resolução de questões conflituosas que são do interesse de toda a comunidade. Os participantes desses tribunais tradicionais se valem de provérbios e máximas proferidos em acusação ou defesa. Num litígio, o lado que as conhecer melhor, evocando-as acertadamente em relação à questão em juizo, é reputado sábio, sensato aos olhos da comunidade, e portanto, mais propenso a angariar vereditos favoráveis. Segundo Ruth Finnegan,

Uma das principais linhas de força dos provérbios africanos é o sentido de imparcialidade e generalização a eles inerente, que cria para quem os enuncia como que um distanciamento em relação ao ambiente de discussão acalorada em que se encontra envolvido, direcionando as atenções - se si próprio e dos outros - para as as implicações mais amplas da situação. Ademais, a

91 FINNEGAN, Ruth. Oral Literature in Africa, p. 349. 
natureza obliqua e alusiva do provérbio permite sua utilização proveitosa de muitas diferentes maneiras, particularmente na oratória das demandas judiciais. ${ }^{92}$

De volta ao conto "O Feitiço da Rama de Abóbora", de Tchikakata Balundu, vamos encontrar o personagem Cisoka sendo apresentado a um ondjango de ekanga (julgamento) reunido na casa do soma (chefe), devido à queixa portada por um pastor de ele ter assustado seu gado:

O soba inicia uma sessão de perguntas para averiguar as implicações da queixa. A última pessoa a ser questionada é o réu, que confirma todas as acusações. Neste julgamento, é de notar que o soma não tira os olhos do seu interlocutor, fazendo o mesmo com os conselheiros e com a multidão. Numa resposta dada por Cisoka, este revela possuir dotes de oratória: "quando atiramos uma pedra a alguém esquecemos isso [que é uma ação negativa], mas quem a tiver apanhado não o fará assim tão cedo". O julgamento, por ter difícil decisão, é transferido para o dia seguinte, iniciando-se cedo e só terminando quando "O sol vai no zénite". ${ }^{93}$

Podemos supor que tribunais como esse tenham migrado do espaço dos olondjango angolanos para as assembleias noturnas da diáspora, acionados nas situações em que a comunidade de escravizados tinha de lidar com questões litigiosas internas. O modelo estruturante do ondjango e seus modos de interlocução coletiva certamente figurava na bagagem de princípios civilizatórios comuns compartilhada por ovimbundo e outros banto-descendentes fixados no sudeste brasileiro, no processo de rearticulação de uma cultura identitária de síntese. Também é de se crer que, para os jongueiros, as demandas sempre representaram oportunidade de afirmar seu prestígio perante o grupo, estabelecendo-se, assim, hierarquias e lideranças fundadas no conhecimento da palava ancestral. Pois, como explica o historiador Joseph Ki-Zerbo,

Para o africano, a palavra é pesada. Ela é fortemente ambígua, podendo fazer e desfazer, sendo capaz de acarretar malefícios.

92 FINNEGAN, Ruth. Oral Literature in Africa, p. 395.

93 SÁ, Ana Lúcia Lopes de. Raízes de tradições orais em romances históricos angolanos, p. 15 o. 
É por isso que sua articulação não se dá de modo aberto e direto. A palavra é envolvida por apologias, alusões, subentendidos e provérbios claro-escuros para as pessoas comuns, mas luminosos para aqueles que se encontram munidos das antenas da sabedoria..$^{94}$

Seja qual for a situação que preponderou, na história social dos banto na diáspora sudestina, para a configuração da modalidade jongo de demanda - as justas poéticas ou os tribunais tradicionais (ekanga)-, é bastante claro que o espaço jongueiro se abre, até os dias atuais, para a encenação ritualizada, dialógica e coletiva dos conflitos da comunidade através de elocuções metafóricas, mesmo se as fórmulas de sabedoria ancestral se perdem na bruma dos tempos ${ }^{95}$.

\section{Espaço de celebração da vida}

Já em relação à sua forma festiva e lúdica, com canto, dança e toques de tambores, o jongo pode estar ligado ao okupapala, celebração coletiva que acontece quando a assembléia do ondjango se reune para ações solidárias, na modalidade conhecida como ondjuluka/otchipito (solidariedade). São encontros de planejamento coletivo ou para realizar ações comunitárias em mutirão: receber e alojar pessoas que chegam à comunidade para algum evento familiar, preparação para as caçadas em grupo, para a guerra ou para os julgamentos. Durante este tipo de reunião pode acontecer o okupapala,

a festa, a dança, o lúdico da vida, momento de entretenimento. [...] A vida tem sua realização na festa. Todos os momentos devem ser celebrados. [Diz] o cântico: nda oli komwenho papala, omwenho wokaliye otchinimbu-[...]"se estiveres com a vida (vivo), brinca e festeja porque a vida hodierna é breve". ${ }^{96}$

Provavelmente os pontos cantados em contexto de ludicidade corporal, prevalesceram no jongo vale-paraibano, mais do que as

94 KI-ZERBO, Joseph (org.). História geral da Africa, p. 28. (Grifos meus)

95 Nos jongos atuais, louvação, visaria e demanda se entrecruzam a todo instante no serenar da ingoma (desenrolar da roda), o que não interrompe seu fluxo de transitividade, reentabulando-se, por exemplo, uma demanda entre dois jongueiros cortada por um ponto de louvação ou visaria de um terceiro.

96 KAVAYA, Martinho. Educação, cultura e cultura do "Amém”: diálogos do Ondjango com Freire em Ganda-Benguela/Angola, p.158. 
formas discursivas faladas, por favorecerem (somando-se a isso a poética de duplo sentido) o encobrimento das verdadeiras vocações daquelas assembléias de negros; aos olhos e ouvidos dos brancos, elas apareceriam, sempre, como festas ao som de tambores, cantos e danças de divertimento (e por vezes o eram, de fato...).

Quanto à articulação da celebração jongueira com o trabalho solidário, ainda pode ser observada em lugares onde se preserva a pequena propriedade rural e seus modos tradicionais de relacionamento vicinal, como nos municípios paulistas de Lagoinha e Cunha. Nos trabalhos coletivos de capina conhecidos como puchirões, o ritmo das enxadas escande os versos cantados em duplas pelos camaradas, contendo enigmas (linha) e louvações (amizade). Ao término destes, o esforço de todos é coroado com o oferecimento, pelo dono da casa, de uma refeição, seguida de um jongo, que pode durar até o sol raiar.

Por fim, um aspecto não menos importante da celebração jongueira a ser destacado como paralelo ao ondjango é a refeição coletiva. $\mathrm{Na}$ instituição angolana, a partilha de alimento é chamada de ekuta: o alimento preparado pelas esposas dos participantes do ondjango é levado pelos jovens, quando findam os trabalhos do dia ou antes da partida para o trabalho, e repartido entre todos. Nos jongos, nunca falta a tradicional canja, preparada pelo festeiro do ano e servida gratuitamente a todos os presentes na roda quando a chega a madrugada ${ }^{97}$.

\section{Conclusão: do ondjango ao jongo}

A tentativa de aproximação especulativa entre o ondjango ovimbundo de Angola e o jongo do sudeste do Brasil permitiu, ainda no campo das hipóteses, resgatar significados primevos do termo jongo: onjó, casa ou lugar, de reunião comunitária para o ohango, uso coletivo e dialogado da palavra. Onjó de crônica social, onjó de veiculação da tradição ancestralem formulações de sentido simbólico, onjó de narrativa de vida, onjó de resolução de conflitos, onjó de solidariedade ede celebração coletiva. A existência de múltiplas articulações de sentido coincidentes, e historicamente tramadas, entre onjango e jongo, projeta a sua dimensão de lugar da fala, em consonância com princípios civilizatórios africanos de centralidade da palavra.

97 Note-se que a distribuição de alimentos também é observada em outras celebrações populares, independentemente de terem matrizes africanas. 
Seria o jongo uma rearticulação diaspórica do ondjango angolano, ou de alguns de seus aspectos, ressignificados e retrabalhados pelos banto-descendentes em resposta às condições restritivas da escravidão? Portadores dessa instituição ancestral africana, povos deportados dos antigos reinos do Ndongo, de Matamba, do Kongo tiveram de fazer frente ao projeto deculturador e despersonalizador do escravismo colonial brasileiro, e para isso se valeram do bem mais precioso que guardavam: a palava falada. Ela foi a argamassa que permitiu reconstruir, entre os escombros do cativeiro, uma civilização neobanto no Brasil, uma cultura de síntese com língua própria, vida religiosa, formas de lazer e instâncias de reunião e decisão coletiva.

A noite que precedia a folga semanal dos escravizados, momento propício da articulação comunal, acolhia em torno da grande fogueira os antepassados e os viventes, para a realização de mais um ondjango na diáspora. Naquele pequeno lapso de tempo, a palavra compartilhada em diálogo de igual para igual permitia resolver as coisas, lograva reacender a chama da vida social interrompida pela corveia diária e reatar os fios que ligam à ancestralidade. Assim se reafirmava a bantuidade de cada um, para além das diferenças de etnia.

Mas naquela roda noturna sempre havia casca de coco, gente de fora, com olhos e ouvidos bem atentos. As falas eloquentes e as longas narrativas sob o luar aqui não eram possíveis, despertando a desconfiança dos patrões. As elocuções desses olondjango afrobrasileiros foram, então, se limitando às formas curtas inspiradas na literatura oral africana, que encerravam em seus versos concentrados e alusivos um mundo de ideias e significados. Com sua vocação circunstancial e apaziguadora de conflitos, a linguagem proverbial garantia o entendimento no interior do grupo de cativos, que detinham sua chave simbólica e assim se fortaleciam, ao mesmo tempo que tranquilizava o casca de coco - na sua ingenuidade, ele até que se divertia com a singeleza das imagens de plantas e bichos. E os modos ondjanguianos de interlocução - ulonga, ombangulo, ekanga -, fundamente enraizados, se imiscuem com sutileza nas canções, amoldando-as segundo as situações comunicacionais que se sucedem no terreiro: louvação, visaria, demanda. Para maior eficácia do necessário jogo de dissimulação, a fala transmuta-se em puro canto, o canto atrai o tambor, o tambor puxa a dança. É sob esse tripé festivo do okupapala, tão africanamente brasileiro, que o jongo se firma. Está formada a roda. 


\section{Sobre o autor}

\section{Paulo Dias}

Músico, etnomusicológo e pesquisador da cultura popular tradicional. É presidente da Associação Cultural Cachuera! (www.cachuera.org.br), entidade voltada para o registro, divulgação e reflexão sobre a música popular tradicional brasileira.E-mail: paulodias@cachuera.org.br 
